\title{
Research on the Causal Relationship between Antecedent Factors, Tourist Satisfaction and Destination Loyalty
}

\author{
Zhu Mingfang and Zhang Hanyu
}

\begin{abstract}
The satisfaction measures are often required by a theoretical construct in system of cause-effect relationships. Many scholars consider causal linkage between the causes and results of consumer satisfaction as a key focus. However, it was shown that more than $\mathbf{3 0}$ factors are used in different research as antecedents and/or evaluative factors for destination satisfaction and loyalty. Thus leave room for further research in this controversial topic. The objective of this paper is to develop an acceptable theoretical model based on major established behavioral theories and attribute-level approach. The theoretical model will include intrinsic, extrinsic (brand, warranty, price) cues, quality, risk, destination image, tourist attributes and satisfaction. The model needs further research on its generality and robustness.
\end{abstract}

Index Terms-Tourist satisfaction, destination loyalty, antecedent factor.

\section{INTRODUCTION}

\section{A. Introduce the Problem}

Without doubt, some key decisions on products and services provided by destinations is following outcome of satisfaction analysis. Tourist satisfaction is widely accepted as being of central reference to destination management organization and tourism-related sectors. High tourist satisfaction contributes to enhanced reputation of tourism product providers and of the whole destination. It also increases consumer loyalty, lower cost of future transactions and reduced price elasticity [1], [2].

The consumer satisfaction assessment has attracted interest from many scholars and industry representatives, which led to the development of various national and regional consumer satisfaction indexes. It is common for tourism-related businesses, government agencies and scholars to carry out tourist satisfaction surveys at both the micro (sector) and macro (destination) levels. Less effort put into understanding the influencing factors which will lead to higher satisfaction in future. Fortunately, the satisfaction measures are often required by a theoretical construct in system of cause-effect relationships. More and more scholars consider causal linkage between the causes and results of consumer satisfaction as a key focus

While most present theoretical models of causal relationship of satisfaction either utilized models

Manuscript received January 2, 2014; revised March 3, 2014. This work was supported in part by Innovation Foundation of Jinan University.

Zhu Mingfang is with the Shenzhen Tourism College of Jinan University, China (e-mail: zhu_mf@sz.jnu.edu.cn).

Zhang Hanyu is with the Department of Hotel and MICE, Shenzhen Tourism of Jinan University (e-mail: zhang_hy@sz.jnu.edu.cn; corresponding author: Zhang Hanyu). expectation/disconfirmation extending to tourist characteristics like Song et al.(2010) and ACSI, or attempt to utilize destination image, marketing program as antecedents of satisfaction. None tried to study the relationship between overall TSI, attribute TSI, tourist attributes, destination image and other factors. It is complicated because of locating antecedents of tourist satisfaction and destination loyalty.

\section{B. Explore Importance of the Problem}

Reasons listed in the following paragraphs.

Firstly, Tourism is a high-integrated system that has a number of sectors such as accommodation, transportation, catering, travel intermediaries (tour operators and travel agencies), retailing, visitor attractions and tourism-related public agencies. Hence, tourists overall satisfaction is affected by each component involved in tourist's experiences at the destination. Although many tourism businesses body have been carrying out tourist satisfaction surveys , and also launched one-off tourist satisfaction investigations at destination level, there has not been a continuous evaluation system which facilitates the assessment of tourist satisfaction on a basis at both sectoral and destination levels.

Secondly, many bodies acknowledged a high customer defection despite satisfaction ratings [3]. High survey satisfaction index do not guarantee the increase the number of visitors and improve the destination's revenue. Based on this, some researchers criticize the mere satisfaction measurement and shift to the study of causal relationship of satisfaction. The mere satisfaction indices and measures are often required by a theoretical construct in system of cause-effect relationships. Many scholars consider causal linkage between the cause and results of consumer satisfaction as a key focus [3]-[5].

Thirdly, it was shown that more than 30 factors are used in different research as antecedents and/or evaluative factors for loyalty. Thus leave room for further research in this controversial topic.

This study aims to solve above problem by adopting a model of the antecedents and satisfaction decisions. The theoretical framework of tourist satisfaction evaluation guide government agencies, sectors of the tourism industry and the public with needed information for decision-making and planning. And the causal framework of tourist satisfaction and destination loyalty provides related stake holders the influencing factors between tourist and destination revenues.

\section{RELATED LitERATURE REVIEW}

\section{A. Satisfaction Evaluation}

Various companies draw a lot of attention to monitor the 
satisfaction level of their consumers over time due to its importance. A number of satisfaction barometers or indices have been developed for products and services in the last decades. Among research papers, expectation/ disconfirmation is most popular model among studies conducted to evaluate consumer satisfaction. The other widely used version includes the American customer satisfaction index (ACSI) operating since 1994, Swedish customer satisfaction barometer (SCSB) operating since 1989, and the Norwegian customer satisfaction barometer since 1996. The last model was modified and improved from time to time (Michael D. Johnson et al., 2001). Generally, five elements are expectation, disconfirmation, perceived performance, satisfaction and customer loyalty.

As an integrated system consisting of sectors such as accommodation, catering, transportation, attractions, and so on, tourism industry needs to be considered as a whole system when assessing tourist satisfaction. Hence, some modifications should be made to satisfy the tourist destination on benchmarking tourist satisfaction index (TSIs) Moreover, tourists list all potential destinations when making decisions on where to vacation. Within a destination, many no-relevant businesses as well as local government organizations affect the visitor experience and post-purchase behavior in different ways. Benchmarking overall destination tourist satisfaction is challenging since so many different elements involved in tourist satisfaction (Oliver, Swan, 1989). Tourism researchers show interests in measuring both overall tourist satisfaction [6] and tourist satisfaction at the service sector level , like Restaurants, accommodation, Travel agencies, Attractions, Retail shops, Packaged tours[7]-[12].

Although the research has gained increasing popularity at both levels, few overall TSIs are aggregated based on specific service/production. One of the major contributions of this study is to study the association between tourist satisfaction with tourism-related sectors and the overall destination satisfaction. Haiyan Song et al. (2010) proposed the Hong Kong PolyU TSI to monitor the changes of tourist satisfaction on both levels. Taken Industry/sector-level TSIs into consideration, a sound theoretical framework similar to ACSI aggregated to overall destination satisfaction based on the sectoral-level satisfaction. This weighting aggregation scheme of TSI used by Haiyan Song et al. (2010) is quite good for consuming goods and service and free-of-charge public services which a tourist encounters during the visit. However, it shows the hypothesized path between tourist characteristics and other constructs are not significant according to theoretical framework adopted by Song et al. (2003). The tourist characteristics should apply influence to tourist satisfaction in some way and is believed that the model needs to be reconstructed.

The review suggests that there is a great demand for the development of a more concise evaluation system in order to assess tourists' overall satisfaction. Such a system should have a sound theoretical underpinning and is capable of integrating both the sectoral and destination satisfaction levels over time.

\section{B. Causal Relationships of Antecedents, Satisfaction and Loyalty}

Both academics and industries show interests to have good understanding of the overall TSI, attribute TSI, and other antecedents like tourist characteristics, consequences and destination image.

Most models of causal relationship either utilize models expectation/disconfirmation extending to tourist characteristics and ACSI, or attempt to utilize destination image as antecedents of satisfaction. This study try to board the scope of related research among overall TSI, attribute TSI, tourist attributes, destination image and other factors.

Although the major driving forces of tourist satisfaction such as perceived quality, tourist expectations, destination image and perceived value were identified, few investigated the relationship between the tourist characteristics including these driving factors, tourist satisfaction and the revisit intentions.

The academies believe the companies caring most is the causes of tourist satisfaction .The relationships among service qualities, customer attributes and customer satisfaction are viewed and much debated research issue [13]. A review reveals an abundance of studies on satisfaction and tourist motivation, but the relationship among the antecedents, the consequences and the overall satisfaction is not fully investigated the causal relationship of tourist characteristics, satisfaction and destination loyalty have been only conceptually discussed.

Some researchers agree the following sequences and look the destination image or travel motivation as the antecedents of tourist satisfaction:

tourist motivation (destination image) $\longrightarrow$ tourist satisfaction $\longrightarrow$ destination loyalty.

Both Destination image and tourist travel motivation are considered as causes of tourist satisfaction, while tourist loyalty or complaint is listed as the results of satisfaction.

Meanwhile, the firm show interests to the relationship of customer characteristics in consumer satisfaction levels when formulating effective marketing strategies such as product positioning, market segmentation, pricing, (Lai K. Chan et al. 2001). Instead of using tourists'expectations and perceptions of product performance, a tourist characteristics construct is adopted into the hypothetical models utilizing in this research.

\section{Results and Consequences of Satisfaction}

Repeat visits and/or recommendations to others are referred to as tourists' loyalty in most tourism paper, which is one of the key indicators to apply the marketing strategies [14]. Repeat visitors not only provide a source of income, but may also generate positive word of mouth [15].

On the other hand, dissatisfied consumers show intent of existing/switching and voicing their complaints. Since exit/switch cannot directly be measured but can be indirectly represented by loyalty, the study adopts tourist loyalty to reflect the total consequences of tourist satisfaction. The common sense that increased consumer satisfaction will decrease the incidence of complaints and increase appraisals. In other words, loyalty is a proxy for repeat visit, which studies have shown that there are differences in the perception of satisfactions between people. 


\section{CONCEPTRUAL FRAMWORK OF DESTINATON LOYALty}

As we discussed before, this research will focus on the antecedent factors of destination satisfaction and loyalty. To truly understand the plethora of influencing factors on satisfaction thus loyalty, a framework that provides a coherent organization of these factors would be helpful.

The evolution of the model progressed inductively beginning with the causal relationships utilizing expectation/disconfirmation model like ACSI or destination image where literatures we mentioned in the last paragraph. Over about a 5 year period the concepts and propositions behind the model emerged from the ground up, maturing in its present form. In summary form, the grounded research comprised the following elements in progression:

1) Cooperative research with Hong Kong Polytechnic University on tourist satisfaction index at 2009-2010. The outcome includes a serial of reports on TSI of Hong Kong and Shenzhen

2) Feedback, debate and introspection stemming from papers on the topic of destination loyalty presented at several conferences

\section{A. Possible Antecedent Factors}

After reviewing more than 25 empirical studies (Agarwal and Teas (2001, 2004; Petrick 2004a, 2004b; Chi and Qu 2008; Lee, Graefe, and Burns 2007)[16]-[20] (not included all for page limitation), it was found that different authors used more than 30 factors in different research settings as antecedents and/or evaluative factors for loyalty. In fact, a model for loyalty research should incorporates additional contextual factors that may influence the process of consumer choice decision making, like risk and warranty, religious belief etc. As it is too difficult to build a comprehensive model using all factors, we thus developed an acceptable model based on major established behavioral theories and attribute-level approach. Thus the theoretical model will include intrinsic, extrinsic (brand, warranty, price) cues, quality, risk, destination image, tourist attributes and satisfaction.

\section{B. Conceptual Model of Destination Loyalty}

This framework tries to include all the dimensions we discussed before and is provided in Fig. 1.

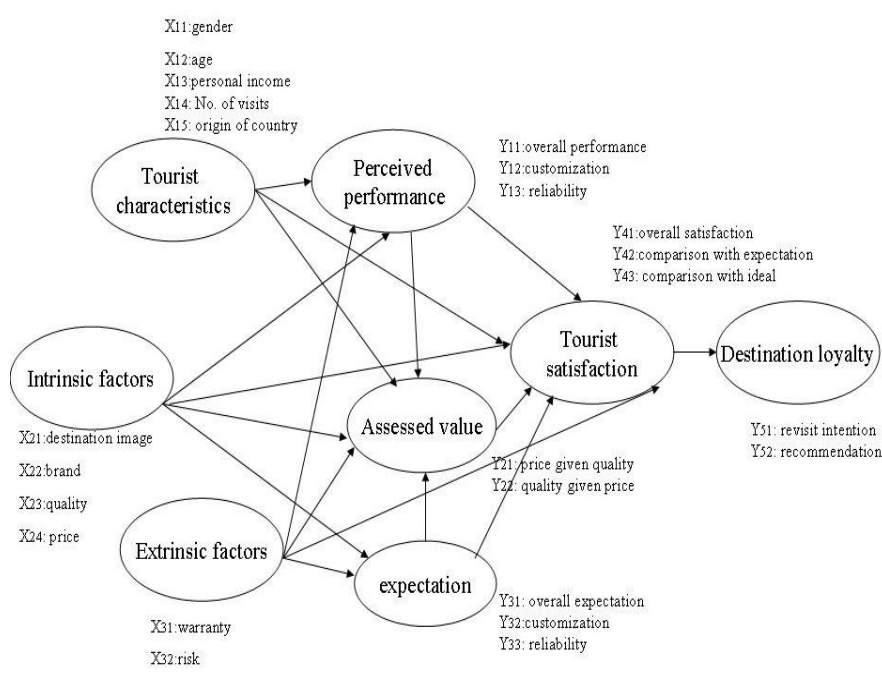

Fig. 1. Conceptual model of destination loyalty.
The proposed theoretical model (see Fig. 1) is based on the expectancy-disconfirmation framework which has been applied in destination satisfaction evaluations. The author includes the tourist characteristics and situational factors (intrinsic and extrinsic factors) as antecedent factors of expectation, perceived performance, assessed value and tourist satisfaction which extend the general expectancy-disconfirmation framework to be a second step model. The researchers could do further study on these to find out the causal relationship between these factors. Whether the tourist characteristics and situational factors affect tourist satisfaction directly or they affect satisfaction via expectation, perceived performance and assessed value. To investigate the causal linkage and address the influential factors of tourists' loyalty to a destination, in particular their revisit intention and recommendation intendancy has an important value for policy-makers for future destination modification and marketing program.

\section{Supposed Methodology}

This study will administer a questionnaire which use 6 point likert scale ( $1=$ Strongly Disagree and $6=$ Strong Agree $)$ as a first wave of data collection of a large research project. To ensure a high level of clarity, the questionnaire will be translated through the double translation method.

Partial least Squares (PLS) v.3.00 was used to analyze the data as it is most appropriate as the model incorporated both formative and reflective indicators [21]. PLS considers all path coefficients simultaneously (thus allowing analysis of direct, indirect, and spurious relationships) and estimates multiple individual item loadings and weights [22]. Besides, PLS can deals minimum sample of 100 [23]. It does not require distributional assumption about sample data. The primary goal of this research is to investigate the antecedent determinants of destination loyalty (i.e., explaining variance) in an exploratory rather than confirmatory mode, (as it is part of $\mathrm{PhD}$ ) rendering prediction-based structural equation modeling (i.e., PLS) more appropriate [25].

\section{CONCLUSION}

Both academics and industries believes the good understanding of the overall TSI, attribute TSI, and other antecedents like tourist characteristics, consequences and destination image is a major topic in destination management. Destination loyalty is very complicated and heterogeneous whose influencing factors have attracted more attention. Antecedent factors have been studied as an efficient means to improve destination loyalty. Most models of causal relationship either utilize models expectation/disconfirmation extending to tourist characteristics and ACSI, or attempt to utilize destination image as antecedents of satisfaction. This study proposed a conceptual model of the causal relationships try to board the scope of related research among overall TSI, attribute TSI, tourist attributes, destination image and other factors.

Although the major driving forces of tourist satisfaction such as perceived quality, tourist expectations, destination image and perceived value were identified, few investigated the relationship between the tourist characteristics including 
these driving factors, tourist satisfaction and the revisit intentions.Our conceptual model of causal relationships between antecedent factors and tourist satisfaction, destination loyalty needs more scrutiny to prove its generality and robustness.

\section{REFERENCES}

[1] E. W. Anderson, C. Fornell, and D. R. Lehmann, "Customer satisfaction, market share, and profitability: Findings from Sweden,' The Journal of Marketing, vol. 58, no. 3, pp. 53-66, 1994.

[2] S. R. Swanson and S. W. Kelley, "Service recovery attributions and word-of-mouth intentions," European Journal of Marketing, vol. 35, no. 1, pp. 194-211, 2001.

[3] R. L. Oliver, "A cognitive model of the antecedents and consequences of satisfaction decisions," Journal of Marketing Research, vol. 17, no. 4, pp. 460-469, 1980.

[4] C. Fornell, "A national customer satisfaction barometer: The Swedish experience," Journal of Marketing, vol. 56, no. 1, pp. 6-21, 1992.

[5] C. Fornell, M. D. Johnson, E. W. Anderson, J. Cha, and B. E. Bryant, "The American customer satisfaction index: Nature, purpose, and findings," Journal of Marketing, vol. 60, no. 4, pp. 7-18, 1996.

[6] L. Yu and M. Goulden, "A comparative analysis of international tourists' satisfaction in Mongolia," Tourism Management, vol. 27, no. 6, pp. 1331-1342, 2006.

[7] D. D. Chadee and J. Mattsson, "An empirical assessment of customer satisfaction in tourism," The Service Industries Journal, vol. 16, no. 3 , pp. 305-320, 1996.

[8] F. Saleh and C. Ryan, "Client perceptions of hotels: A multi-attribute approach," Tourism Management, vol. 13, no. 2, pp. 163-168, 1992.

[9] G. Leblanc, "Factors affecting customer evaluation of service quality in travel agencies: An investigation of customer perceptions," Journal of Travel Research, vol. 30, no. 4, pp. 10-16, 1992.

[10] P. W. Dorfman, "Measurement and meaning of recreation satisfaction: A case study in camping," Environment and Behavior, vol. 11, no. 4 pp. 483-510, 1979.

[11] Y. Reisinger and L. W. Turner, "The determination of shopping satisfaction of Japanese tourists visiting Hawaii and the Gold Coast compared," Journal of Travel Research, vol. 41, no. 2, pp. 167-176, 2002.

[12] A. Pizam and A. Milman, "Predicting satisfaction among first time visitors to a destination by using the expectancy disconfirmation theory," International Journal of Hospitality Management, vol. 12, no. 2, pp. 197-209, 1993.

[13] Y. Yoon and M. Uysal, "An examination of the effects of motivation and satisfaction on destination loyalty: A structural model," Tourism Management, vol. 26, no. 1, pp. 45-56, 2005.

[14] M. Kozak and M. Rimmington, "Tourist satisfaction with Mallorca, Spain, as an off-season holiday destination," Journal of Trave Research, vol. 38, no. 3, pp. 260-269, 2000.

[15] A. L. S. Lau and B. McKercher, "Exploration versus acquisition: A comparison of first time and repeat visitors," Journal of Travel Research, vol. 42, no. 3, pp. 279-285, 2004.
[16] S. Agarwal and R. K. Teas, "Perceived value: Mediating role of perceived risk," Journal of Marketing Theory and Practice, vol. 9, no. 4, pp. 1-14, 2001.

[17] J. F. Petrick, "Are loyal visitors' desired visitors?" Tourism Management, vol. 25, pp. 463-470, 2004.

[18] J. F. Petrick, "The roles of quality, value, and satisfaction in predicting cruise passengers' behavioral intentions," Journal of Travel Research, vol. 42, pp. 397-407, 2004

[19] G. O. C. Chi and H. Qu, "Examining the structural relationships of destination image, tourist satisfaction and destination loyalty: An integrated approach," Tourism Management, vol. 29, pp. 624-636, 2008.

[20] J. Lee, A. R. Graefe, and R. C. Burns, "Examining the antecedents of destination loyalty in a forest setting," Leisure Sciences, vol. 29, pp. 463-481, 2007.

[21] W. W. Chin, "The Partial least square approach to structural equation modeling in modern methods for business research," in Mahwah, G. A Marcoulides, ed., NJ: Lawrence Erlbaum, pp. 295-336, 1998.

[22] C. J. White, R. P. Varadarajan, and P. Dacin, "Market situation and response: the role of cognitive style, organizational culture, and information use," Journal of Marketing, vol. 67, pp. 63-79, 2003.

[23] W. W. Chin and P. R. Newsted, "Structural equation Modeling analysis with small samples using partial least squares," in Statistical Strategies for Small Sample Research, R. H. Hoyle, Ed., Sage, Thousand Oaks, CA, 1999

[24] L. K. Chan, Y. V. Hui, H. P. Lo, S. K. Tse, G. K. Tso, and M. L. Wu, "Consumer satisfaction index: New practice and findings," European Journal of Marketing, vol. 37, no. 5/6, pp. 872-909, 2003.

[25] R. Echambadi, B. Campbell, and R. Agarwal, "Encouraging best practice in quantitative management research: An incomplete list of opportunities," Journal of Management Studies, vol. 43, no. 8, pp. 1801-20, 2006.

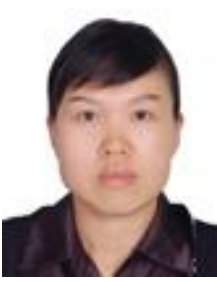

Mingfang Zhu is an associate professor of tourism management in Shenzhen Tourism College of Jinan University. She received PHD degree in management in 2009 from Tongji University, China. Her research interests are destination marketing and tourism management.

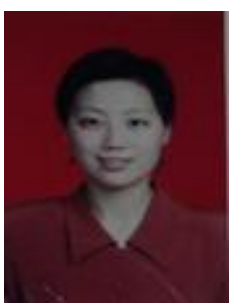

Zhang Hanyu is an associate professor in Senzhen Tourism College of Jinan University, research mainly on tourism destination management, organizational behavior and institutional change. 